\title{
Evaluation of posttraumatic recurrent bacterial meningitis in adults
}

\author{
Özcan Deveci, M.D., ${ }^{1}$ Cem Uysal, M.D., ${ }^{2}$ Sefer Varol, M.D., ${ }^{3}$ Recep Tekin, M.D., ${ }^{1}$ \\ Fatma Bozkurt, M.D., ${ }^{1}$ Muhammed Bekçibaşı, M.D., ${ }^{4}$ Salih Hoşoğlu, M.D. ${ }^{1}$ \\ ${ }^{1}$ Department of Infectious Diseases and Clinical Microbiology, Dicle University Faculty of Medicine, Diyarbakir \\ ${ }^{2}$ Department of Forensic Medicine, Dicle University Faculty of Medicine, Diyarbakir \\ ${ }^{3}$ Department of Neurology, Dicle University Faculty of Medicine, Diyarbakir \\ ${ }^{4}$ Department of Infectious Diseases and Clinical Microbiology, Bismil State Hospital, Diyarbakir
}

\begin{abstract}
BACKGROUND: Acute bacterial meningitis may develop as a complication after head trauma. The aim of this study was to present the demographic, clinical, microbiological and radiological characteristics of adult patients who presented with recurrent bacterial meningitis attacks after trauma.

METHODS: Using a retrospective approach, the medical records of patients with acute recurrent bacterial meningitis (RBM) were reviewed, and those who had a history of trauma were included into the study. RBM was diagnosed based on clinical, bacteriologic and laboratory results. Demographic characteristics, clinical course, laboratory test results including cerebrospinal fluid analysis (CSF), radiological images, and the applied treatments were evaluated.
\end{abstract}

RESULTS: A total of two hundred and twelve patients with acute bacterial meningitis were included into the study. RBM was diagnosed in twenty-five patients ( $11.8 \%)$, and in 18 of these patients (8.5\%), the attacks had occurred subsequent to a trauma. In the CSF cultures of four patients, S. pneumoniae growth was observed. CT cisternography indicated CSF leaks in eleven patients. Moreover, bone fractures were observed in the CT images of ten patients. Ceftriaxone therapy was prescribed to $83 \%$ of the patients. Eight patients had a history of a fall in childhood, and five were involved in traffic accidents before acute bacterial meningitis. Four of the patients developed epilepsy and one developed deafness as sequelae.

CONCLUSION: Since RBM attacks are frequently observed following trauma, in patients with a history of trauma who present with meningitis, the risk of recurrence should be considered.

Key words: Meningitis; posttraumatic; recurrent.

\section{INTRODUCTION}

Acute bacterial meningitis is a life-threatening infection that may cause significant morbidity in the cranial and spinal leptomeninges. ${ }^{[1]}$ Recurrent bacterial meningitis (RBM) is defined as the recurrence of the symptoms and clinical and laboratory findings of bacterial meningitis in spite of an adequate

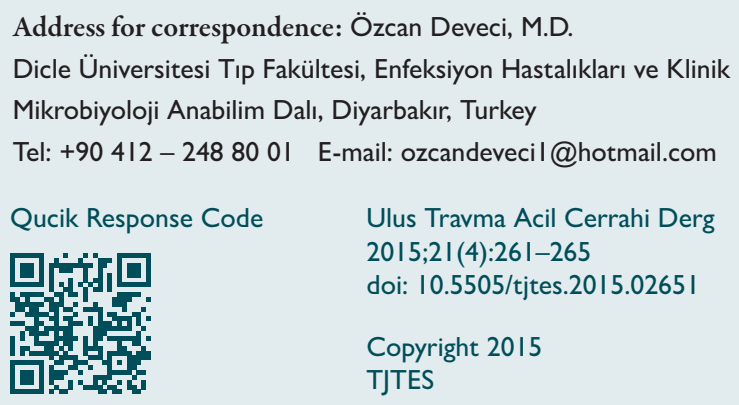

and successful treatment of the previous meningitis attack. ${ }^{[2,3]}$ RBM is a rare entity, suggesting the existence of predisposing causes, among which traumatic causes appear to be the most frequent. ${ }^{[4]}$ Developmental or traumatic disorders may give bacteria access to the subarachnoid space, resulting in RBM. Additionally, undiagnosed immune deficiencies may lead to a susceptibility to the bacteria causing meningitis in affected individuals. Various predisposing factors have been reported. Therefore, the causes paving the way for RBM should be comprehensively investigated. ${ }^{[2]}$ Pneumococcal RBM is usually caused by an intracranial seeding of bacteria via direct communication with an extracranial source. This condition frequently manifests with constant or intermittent cerebrospinal fluid (CSF) rhinorrhoea due to various etiologies. ${ }^{[5]}$ Early diagnosis of any underlying pathologies in patients with recurrent bacterial meningitis is important to prevent further attacks and improve the general outcome in affected patients. Posttraumatic recurrent bacterial meningitis has primarily 
been described in case series of pediatric patients. Studies conducted on adult patients with posttraumatic recurrent bacterial meningitis are limited in number. Since the majority of the previous studies on RBM have included fewer than ten patients, our study may shed greater light to the understanding and management of posttraumatic RBM with the larger number of patients featured. The aim of the present study was to present the demographic, clinical, microbiological, and radiological characteristics of adult patients who presented with recurrent bacterial meningitis attacks after trauma.

\section{MATERIALS AND METHODS}

The study was conducted at the Dicle University Hospital, which is a 1,275-bed tertiary referral center that provides care for the vast majority of patients with bacterial meningitis in south-eastern Turkey. Patients who presented to the Dicle University Hospital with symptoms including headache, fever, nausea and vomiting, and nuchal rigidity during physical examination pointing to meningitis between the years 2003 and 2012 were included into the study in a retrospective manner. After neurology consultation to exclude any cerebrovascular events, the patients were admitted to the Department of Infectious Diseases with a pre-diagnosis of meningitis. Lumbar punctures were performed and the cerebrospinal fluid (CSF) was tested. Patients with a leukocyte count $>1000 / \mathrm{mm}^{3}$ (dominance of polymorphonuclear leukocytes), CSF glucose $<50 \%$ of blood glucose, CSF protein $>50 \mathrm{mg} / \mathrm{dl}$, and/or positive CSF culture were diagnosed with acute bacterial meningitis.

All patients were asked about any previous history of meningitis and trauma preceding the attacks. Recurrent bacterial meningitis was defined as a case of meningitis that developed due to the same or a different microorganism more than three weeks after the completion of the treatment for the initial meningitis attack. The diagnosis of RBM was based on clinical, bacteriological and laboratory results. Patients with ventriculo-peritoneal shunts or immune deficiency were excluded from the study. Since the patients had a history of trauma, cranial tomography (CT), cranial magnetic resonance imaging (MRI) and ventriculo-cisternography results were recorded in patients with risk factors. The mean age, gender, and CSF results of the patients were evaluated. The prescribed antimicrobial treatments were also taken into consideration.

The consent of the Dicle University Medical Faculty Ethics Committee was obtained for this study.

\section{RESULTS}

The total number of patients with acute bacterial meningitis during the study period was two hundred and twelve. Recurrent bacterial meningitis was diagnosed in twenty-five (I I.8\%) of them. Post-traumatic RBM was diagnosed in eighteen (72\%) of the recurrent meningitis patients. The age range of these patients was between 17 and 63 years, and the mean age was 28 years. Among the patients, eight were female while ten were male. A total of eighteen patients with forty-three meningitis episodes were recorded. The mean number of the episodes was $2.6 \pm 0.8$ (range, 2-5 episodes). Seven patients had a history of fall from height during their childhood, and five had a history of traffic accident.

When the CSF test results of the patients were assessed, CSF pressure was observed to be increased in the majority of the patients. CSF was turbid, and the mean CSF glucose was lower than $50 \%$ of the blood glucose level. These CSF results were consistent with acute bacterial meningitis. Grampositive growth was the most frequently observed growth type. S. pneumoniae growth was observed in the CSF cultures of four patients. Gram staining indicated gram-positive diplococcus in four patients (Table I).

Radiological imaging results of the patients showed bone fractures and dural contrast enhancement in the brain CT images of seven patients, dural contrast enhancement in the brain MRI of thirteen $(72.2 \%)$ patients, and bone fractures in ten $(55.6 \%)$ patients. Among the fifteen patients who had undergone cisternographies, eleven had dural defects and eleven had CSF leaks (Table 2). In terms of antibiotic treatment, fourteen out of the eighteen patients $(77.8 \%)$ received ceftriaxone while four patients $(22.2 \%)$ received ceftriaxone+vancomycin. No patients with RBM died during the episodes. Four patients had complications, where three of them developed epilepsy and one developed hearing loss. None of our patients had been on prophylactic antibiotherapy.

Table I. CSF test results

\begin{tabular}{lcc}
\hline Findings & $\mathbf{n}$ & $\%$ \\
\hline Turbid & 17 & 94 \\
Protein level too high to be measured & 13 & 72 \\
CSF glucose/blood glucose $<50 \%$ & 16 & 88 \\
Gram positive diplococcus & 4 & 22 \\
S. pneumoniae growth in the culture & 4 & 22 \\
\hline CSF: Cerebrospinal fluid. & &
\end{tabular}

Table 2. Radiological findings

\begin{tabular}{lcc}
\hline Radiological findings & $\mathbf{n}$ & $\%$ \\
\hline Brain CT dural contrasting & 7 & 39 \\
Brain CT bone fracture & 10 & 55 \\
Brain MRI dural contrasting & 13 & 72 \\
Brain MRI bone fracture & 10 & 55 \\
CSF leak in CT cisternography & $1 \mathrm{I}$ & $6 \mathrm{I}$ \\
\hline CSF: Cerebrospinal fluid. & &
\end{tabular}




\section{DISCUSSION}

Post-traumatic meningitis is an important condition due to its potential for recurrences and sequelae. In some cases, it may even prove fatal. This study underlined that patients with post-traumatic meningitis should be assessed for CSF leakage and the risk of recurrence. Furthermore, healthcare professionals should consider the risk of recurrence in all bacterial meningitis cases.

In a retrospective study evaluating meningitis patients among the general population, $6 \%$ of the patients have been found to have recurrent meningitis. ${ }^{[6]}$ Adriani et al. ${ }^{[7]}$ have conducted a prospective study on meningitis patients among the population in the Netherlands and reported this rate as $5 \%$. However, the rate may be lower in children. In a study by Drummond et al., ${ }^{[8]}$ conducted on pediatric meningitis patients during a ten-year period, the rate of recurrent meningitis has been observed to be only $1.3 \%$. In another study conducted in a tertiary pediatric training and research hospital in Turkey, a rate as high as $6.2 \%$ has been observed for recurrent meningitis, ${ }^{[9]}$ which is higher compared to the previous studies. In our study, radiological assessment pointed out CSF leaks and skull fractures due to trauma. In a study previously conducted at our hospital, Hosoglu et al. ${ }^{[10]}$ had evaluated two hundred and eighteen meningitis episodes in adult patients and reported head trauma as a risk factor for meningitis in seventeen (7.8\%) patients. They had also reported S. pneumoniae as the most prevalent causative agent. In an RBM series from our hospital, twenty-two RBM episodes had been reported in ten patients. Head trauma was a predisposing factor in four of these patients. ${ }^{[1]}$

The spectrum of predisposing factors in RBM is not wide. In a study focusing on patients with recurrent meningitis, $21 \%$ of them has had immune deficiency and $74 \%$ has had congenital, traumatic, or surgical CSF fistulas as predisposing factors. ${ }^{[12]}$ In the literature, there are several case reports on patients with late onset CSF leaks due to head trauma. These fistulas have become apparent within the first month in the majority of cases. ${ }^{[13]}$ In a retrospective study conducted on one hundred and sixty patients with CSF leak due to head trauma, the risk of developing meningitis within the first week following the head trauma has been found as $9.1 \% .^{[14]}$ In our study, the rate of CSF leaks in patients with posttraumatic RBM was observed to be high, which emphasizes the role of trauma in RBM. In a review of case reports on RBM, CSF fistulas due to head trauma have been found to trigger the majority of the recurrent meningitis attacks. According to this review, $28.1 \%$ (102 out of 363 patients) of the recurrent bacterial meningitis cases has occurred secondary to head traumas. However, this review did not distinguish between pediatric and adult patients. ${ }^{[3]}$ The majority of the articles on RBM are either case reports or studies conducted on a limited number of patients. The patients are evaluated as a general study group including both pediatric and adult patients. Only five reports comprised more than five patients. ${ }^{[7,13,15,16]}$ In this respect, our study features a comparatively higher number of adult patients.

In a review by Tebruegge et al., S. pneumoniae has been detected in one hundred (89\%) out of one hundred and twentytwo culture-positive episodes following a head trauma. It is followed by $H$. influenzae and $N$. meningitidis with $6 \%$ and $4 \%$, respectively. When we look at the general causes of recurrent bacterial meningitis, S. pneumoniae was also the leading agent in $72 \%$ of the patients in the same study. ${ }^{[3]}$ In another study from our country conducted on fourteen pediatric RBM patients, eight out of the eleven patients (72.7\%) with bacterial growth had S. pneumoniae in the culture. In the same study, S. pneumoniae growth was also observed in three patients in whom RBM had developed due to a trauma. ${ }^{\left[{ }^{9]}\right.} \mathrm{We}$ also obtained similar results in terms of the causative agents in our study, and S. pneumoniae was the most frequently detected causative agent in culture-positive patients.

Radiological imaging methods are useful to detect CSF fistulas. These methods include CT scans, CT cisternography, radionucleotide cisternography, and MRI. CT cisternography is based on the demonstration of the fistula defect through a contrast agent, and its sensitivity has been reported to be around $55-77 \%{ }^{[16,17]} \mathrm{MRI}$ shows the cerebral tissue and soft tissue thoroughly, which is especially important in case of encephalocele. ${ }^{[18]}$ In a study conducted on twenty-four patients, MRI has been reported to be $100 \%$ sensitive in demonstrating CSF leaks. ${ }^{[19]}$ In an extensive review, all of the CSF leaks detected through MRI have been surgically verified. ${ }^{[3]}$ In our study, CT cisternography was used to show CSF leaks, which were detected at a high rate.

In terms of treatment, in the study by Tuygun et al. ${ }^{[9]}$ in which fourteen pediatric recurrent meningitis patients have been evaluated, all patients have been administered a combination of ceftriaxone and vancomycin. In our study, all patients initially received ceftriaxone. When no response to the initial treatment was observed in four patients, vancomycin was later added to the regimen. Prophylactic antibiotic use in patients with skull base fractures and CSF fistula is controversial. ${ }^{[20,21]}$ In a large-scale study that evaluated the causes of cranial trauma in Turkey, falls from height and traffic accidents were reported as the most common causes. Falls were predominantly observed in male patients. Also in our study, similar causes were observed in terms of the etiology of the cranial trauma. ${ }^{[22]}$ Another review has emphasized the importance of falls during the childhood. ${ }^{[23]}$ Similarly, falls from height and traffic accidents were found as the most frequent causes in our study. Moreover, six out of our seven patients with a history of fall were male. Treatment of CSF fistulas can be surgical or medical. The majority of the CSF leaks are self-limiting and stop spontaneously within 2-7 days the after the trauma. Failure of the conservative treatment is an indication for surgical repair. Profuse leaks, Pneumocephalus, 
delayed and intermittent leaks and recurrent meningitis are absolute indications for surgical treatment. ${ }^{[24]}$ In case of CSF fistulas irresponsive to the medical treatment, surgical treatment should be taken into consideration. Prognosis is very good in patients with spontaneously or surgically closed CSF fistulas. ${ }^{[25]}$

This study has certain limitations due to its retrospective design. In some patients, the history of trauma was based on the statement of the patient or next of kin. In addition, the data on antibiotic treatment before the admission to the hospital was insufficient in some patients.

In case of RBM, patients should be inquired about and examined for any developmental or traumatic anatomic defects or immune deficiency. Since recurrent bacterial meningitis attacks are frequently observed following a trauma, in patients who present with symptoms including headache, nausea, vomiting, and nuchal rigidity, meningitis should be considered in the differential diagnosis. History of any trauma in childhood should be taken seriously since the risk of meningitis might continue throughout the patient's lifetime. After the recovery from the acute phase of bacterial meningitis, the patient should be evaluated for predisposing factors of RBM.

Conflict of interest: None declared.

\section{REFERENCES}

1. Kendirli T, Unay B, Tosun F, Hacihamdioğlu B, Akin R, Ozkaptan Y, et al. Recurrent Streptococcus pneumoniae meningitis in a child with traumatic anterior cranial base defect. Pediatr Int 2006;48:91-3. CrossRef

2. Lieb G, Krauss J, Collmann H, Schrod L, Sörensen N. Recurrent bacterial meningitis. Eur J Pediatr 1996;155:26-30. CrossRef

3. Tebruegge M, Curtis N. Epidemiology, etiology, pathogenesis, and diagnosis of recurrent bacterial meningitis. Clin Microbiol Rev 2008;21:51937. CrossRef

4. Fyfe DA, Rothner DA, Orlowski J, Cook SA. Recurrent meningitis with brain abscess in infancy. Am J Dis Child 1983;137:912-3. CrossRef

5. Pappas DG Jr, Hammerschlag PE, Hammerschlag M. Cerebrospinal fluid rhinorrhea and recurrent meningitis. Clin Infect Dis 1993;17:364-8.

6. Durand ML, Calderwood SB, Weber DJ, Miller SI, Southwick FS, Caviness VS Jr, et al. Acute bacterial meningitis in adults. A review of 493 episodes. N Engl J Med 1993;328:21-8. CrossRef

7. Adriani KS, van de Beek D, Brouwer MC, Spanjaard L, de Gans J. Community-acquired recurrent bacterial meningitis in adults. Clin Infect Dis
2007;45:46-51. CrossRef

8. Drummond DS, de Jong AL, Giannoni C, Sulek M, Friedman EM. Recurrent meningitis in the pediatric patient-the otolaryngologist's role. Int J Pediatr Otorhinolaryngol 1999;48:199-208. CrossRef

9. Tuygun N, Tanir G, Aytekin C. Recurrent bacterial meningitis in children: our experience with 14 cases. Turk J Pediatr 2010;52:348-53.

10. Hoşoğlu S, Ayaz C, Geyik MF, Kökoglu OF, Ozen A. Acute bacterial meningitis in adults: analysis of 218 episodes. Ir J Med Sci 1997;166:231-4.

11. Hoşoğlu S, Ayaz C, Ceviz A, Cümen B, Geyik MF, Kökoğlu OF. Recurrent bacterial meningitis: a 6-year experience in adult patients. J Infect 1997;35:55-62. CrossRef

12. Kline MW. Review of recurrent bacterial meningitis. Pediatr Infect Dis J 1989;8:630-4. CrossRef

13. Friedman JA, Ebersold MJ, Quast LM. Persistent posttraumatic cerebrospinal fluid leakage. Neurosurg Focus 2000;9:1. CrossRef

14. Dunne DW, Quagliarello V. Group B streptococcal meningitis in adults. Medicine (Baltimore) 1993;72:1-10. CrossRef

15. Eljamel MS, Foy PM. Acute traumatic CSF fistulae: the risk of intracranial infection. Br J Neurosurg 1990;4:381-5. CrossRef

16. Maitra S, Ghosh SK. Recurrent pyogenic meningitis-a retrospective study. QJ Med 1989;73:919-29.

17. Schick B, Weber R, Kahle G, Draf W, Lackmann GM. Late manifestations of traumatic lesions of the anterior skull base. Skull Base Surg 1997;7:77-83, CrossRef

18. Chow JM1, Goodman D, Mafee MF. Evaluation of CSF rhinorrhea by computerized tomography with metrizamide. Otolaryngol Head Neck Surg 1989;100:99-105.

19. Manelfe C, Cellerier P, Sobel D, Prevost C, Bonafé A. Cerebrospinal fluid rhinorrhea: evaluation with metrizamide cisternography. AJR Am J Roentgenol 1982;138:471-6. CrossRef

20. Giunta G, Piazza I. Recurrent bacterial meningitis occurring five years after closed head injury and caused by an intranasal post-traumatic meningo-encephalocele. Postgrad Med J 1991;67:377-9. CrossRef

21. Johnson DB, Brennan P, Toland J, O'Dwyer AJ. Magnetic resonance imaging in the evaluation of cerebrospinal fluid fistulae. Clin Radiol 1996;51:837-41. CrossRef

22. Işı1k HS, Gökyar A, Yıldız O, Bostancı U, Ozdemir C. Pediatric head injuries, retrospective analysis of 851 patients: an epidemiological study. Ulus Travma Acil Cerrahi Derg 2011;17:166-72. CrossRef

23. Ongel K, Katirci E, Uludag H, Mergen H, Uzun E, Kisioglu AN. Assesment of fall from high level patients according to publications. Tip Araştırmaları Dergisi 2008;6:175-80.

24. Marentette LJ, Valentino J. Traumatic anterior fossa cerebrospinal fluid fistulae and craniofacial considerations. Otolaryngol Clin North Am 1991;24:151-63.

25. Coşkuner T, Kubilay U, Dalbayrak S, Ünver Ş. Approach to patients with CSF rhinorrhea. J Kartal Tr 2002;13:204-6. 


\section{KLINIK ÇALIŞMA - ÖZET}

\section{Erişkin posttravmatik tekrarlayan menenjitlerin değerlendirilmesi \\ Dr. Özcan Deveci, ${ }^{1}$ Dr. Cem Uysal, ${ }^{2}$ Dr. Sefer Varol, ${ }^{3}$ Dr. Recep Tekin, ${ }^{1}$
Dr. Fatma Bozkurt, ${ }^{1}$ Dr. Muhammed Bekçibaşı, ${ }^{4}$ Dr. Salih Hoşoğlu ${ }^{1}$}

${ }^{1}$ Dicle Üniversitesi Tıp Fakültesi, Enfeksiyon Hastalıkları ve Klinik Mikrobiyoloji Anabilim Dalı, Diyarbakır

${ }^{2}$ Dicle Üniversitesi Tıp Fakültesi, Adli Tıp Anabilim Dalı, Diyarbakır

${ }^{3}$ Dicle Üniversitesi Tıp Fakültesi, Nöroloji Anabilim Dalı, Diyarbakır

${ }^{4}$ Bismil Devlet Hastanesi, Enfeksiyon Hastalıkları ve Klinik Mikrobiyoloji Kliniği, Diyarbakır

AMAÇ: Akut bakteriyel menenjit kafa travmalarının bir komplikasyonu olarak gelişebilir. Bu çalışmanın amacı kafa travmaları sonrası gelişen erişkin tekrarlayan bakteriyel menenjit (TBM) olgularının demografik, klinik, mikrobiyolojik ve radyolojik özelliklerini sunmaktır.

GEREÇ VE YÖNTEM: Çalışma geriye dönük olarak yapıldı. TBM gelişen olguların medikal kayıtları değerlendirildi. Bunlardan kafa travması öyküsü olanlar çalışmaya alındı. TBM tanısı klinik, bakteriyolojik ve laboratuvar testleri kullanılarak konuldu. Hastaların demografik özellikleri, klinik gidişi, beyin omurilik sIVISı (BOS) test sonuçları, radyolojik görüntüleme ve hastaların tedavileri değerlendirildi.

BULGULAR: Toplam 212 akut bakteriyel menenjitli hasta çalışmaya dahil edildi. TBM hastaların sayısı 25 idi (\%।I.8). Bunların da I8'i travmayı takiben gelişen ataklardı. Dört hastanın BOS kültüründe S. pneumonia üremesi gözlendi. Beyin tomografisi (BT) sisternografisi II hastada kaçağı gösterdi. Ayrıca on hastanın BT incelemesinde kemik kırı̆̆ı gözlendi. Hastaların \%83'üne seftriakson tedavi olarak verildi. Akut bakteriyel menenjit öncesi sekiz hastada çocukluk çağında düşme ve beş hastada trafik kazası öyküsü vardı. Dört hastada epilepsi ve bir hastada sağılık gelişti.

TARTIŞMA: Tekrarlayan bakteriyel menenjit sıklıkla travmayı takiben geliştiğinden dolayı, travma hikayesi olan menenjitli hastaların tekrar gelişme riski açısından göz önünde bulundurulması gerekir.

Anahtar sözcükler: Menenjit; posttravmatik; tekrarlayan.

Ulus Travma Acil Cerrahi Derg 20 I5;2I (4):26I-265 doi: I0.5505/tjtes.20I5.0265 I 